\section{The Vegetative Response of 'Concord' Grapevines to Soil pH}

\author{
Terence R. Bates, Richard M. Dunst, Theodore Taft, and \\ Michael Vercant \\ Department of Horticultural Sciences, Cornell University VineyardLaboratory, \\ Fredonia, NY 14063
}

Additional index words. roots, rhizosphere, mineral nutrition, Vitis labruscana

\begin{abstract}
One- and 2-year-old 'Concord' (Vitis labruscana L.) grapevines were used to study the effect of soil pH on vegetative growth and nutrition. Ninety-eight, own-rooted, 'Concord' grapevines were planted in 94.6-L pots containing vineyard soil adjusted to seven soil $\mathrm{pH}$ levels ranging from 3.5 to 7.5. After the first growing season, seven vines from each soil pH treatment were randomly selected, destructively harvested, and measured for root and shoot growth. The remaining 49 vines over-wintered in the pots, were defruited in year two, and were destructively harvested at the end of the second growing season. There was a reduction in root biomass below soil $\mathrm{pH}$ of 4.5 and a greater reduction in shoot biomass leading to a higher root : shoot ratio. There were no significant differences in vegetative growth of young 'Concord' vines from a soil $\mathrm{pH}$ of 5.0-7.5. However, there was a trend toward lower shoot biomass and higher root : shoot ratio at the highest soil pH level. Phylloxera nodosities on roots were present in equal densities at all soil pH values. However, the negative impact of phylloxera on vine dry mass was greater on vines under nutrient stress at the highest and lowest $\mathrm{pH}$ treatments than on those with adequate nutrition at the mid-range soil $\mathrm{pH}$ values.
\end{abstract}

Lake Erie Regional Grape Belt soils in New York and Pennsylvania vary in texture, organic matter, $\mathrm{pH}$, aeration, and moisture holding capacity (Feuer et al., 1955). Low soil $\mathrm{pH}$, which is characteristic of these soils, affects nutrient availability and root growth (Feuer et al., 1955; Lathwell and Reid, 1984). In a 1934 study, Chautauqua county 'Concord' vineyards had a soil $\mathrm{pH}$ average of 5.4 and a yield average of $3.8 \mathrm{t} \cdot \mathrm{ha}^{-1}$ (Oskamp, 1934). In a 1997 soil sample survey taken by the Lake Erie Regional Grape program, vineyards had a soil pH average of 4.5 (Fig. 1) and a yield average of $11.3 \mathrm{t} \cdot \mathrm{ha}^{-1}$. While the 'Concord' grape industry has increased yield through a variety of viticulture practices, the average soil $\mathrm{pH}$ has decreased, presumably from the repeated yearly application of acidifying ammonium nitrate or urea fertilizers (Hanson, 1996; Marschner, 1986). One-yearold 'Concord' cuttings did not show a growth difference when grown in pot culture at soil $\mathrm{pH} 6.7$ or 4.8 , indicating the potential acid tolerance of Vitis labruscana (Himelrick, 1991). From 1958 to 1968, a 'Concord' study in Erie County, Pa., did not show an effect of calcitic or dolomitic limestone on vine growth or yield (surface application rates of 6.8-18.0 t.ha ${ }^{-1}$ over a 3-year period) (Smith et al., 1972). However, in that study, the limestone treatments only changed the soil $\mathrm{pH}$ in the upper $7.6 \mathrm{~cm}$ of soil where the limestone was incor-

Received for publication 1 July 2001. Accepted for publication 7 Apr. 2002. We thank Christine Cummings, Eileen Eacker, and Paula Joy for their viticulture assistance and Phil Throop for the vineyard survey information. This research was supported by the New York Wine and Grape Foundation and the Eastern Viticulture Consortium. dolomitic limestone application. Often, this problem is exaggerated by dry soil conditions, which limits potassium availability in unirrigated vineyards, or by high crop level, which increases vine potassium demand (Shaulis, 1961; Shaulis and Kimball, 1956). Together, these studies have led to the recommendation against the addition of limestone to 'Concord' vineyards in western New York, despite soil $\mathrm{pH}$ values below 5.0 in a majority of vineyards.

Although excessive hydrogen ions in the soil solution can have an effect on root cell membrane potential, low $\mathrm{pH}$ itself does not inhibit root growth. However, as the soil $\mathrm{pH}$ decreases from 5 to 3.5 , aluminum solubility increases, and it is the free and exchangeable aluminum ions that affect nutrient availability and root growth (Marschner, 1986). High free aluminum precipitates phosphorus, making phosphorus unavailable to the plant, and exchangeable aluminum displaces calcium and magnesium, decreasing their availability (Foy, 1992). In most plant systems, aluminum toxicity has a direct effect on root growth by inhibiting cell division in the root apical meristem (Kochian, 1995). In spite of this, some species have developed strategies to avoid soil chemical stress and increase nutrient acquisition efficiency. In response to poor nutrient availability, roots generally have been shown to change growth patterns, to stimulate ion uptake and transport, to modify the rhizosphere chemistry, and to form associations with beneficial microorganisms in order to increase nutrient acquisition efficiency (Waisel et al., 1996). The rhizosphere refers to the root-soil interface and it can differ substantially from the bulk soil in ion concentration, $\mathrm{pH}$, redox potential, root exudates, organic carbon, and microbial activity. Nutrient availability in the bulk soil is a function of the soil chemical characteristics, a passive characteristic. Nutrient availability in the rhizosphere is a function of root physiology and biochemistry, an active process. Differential anion-cation uptake, proton pumping, chelating and reducing com-

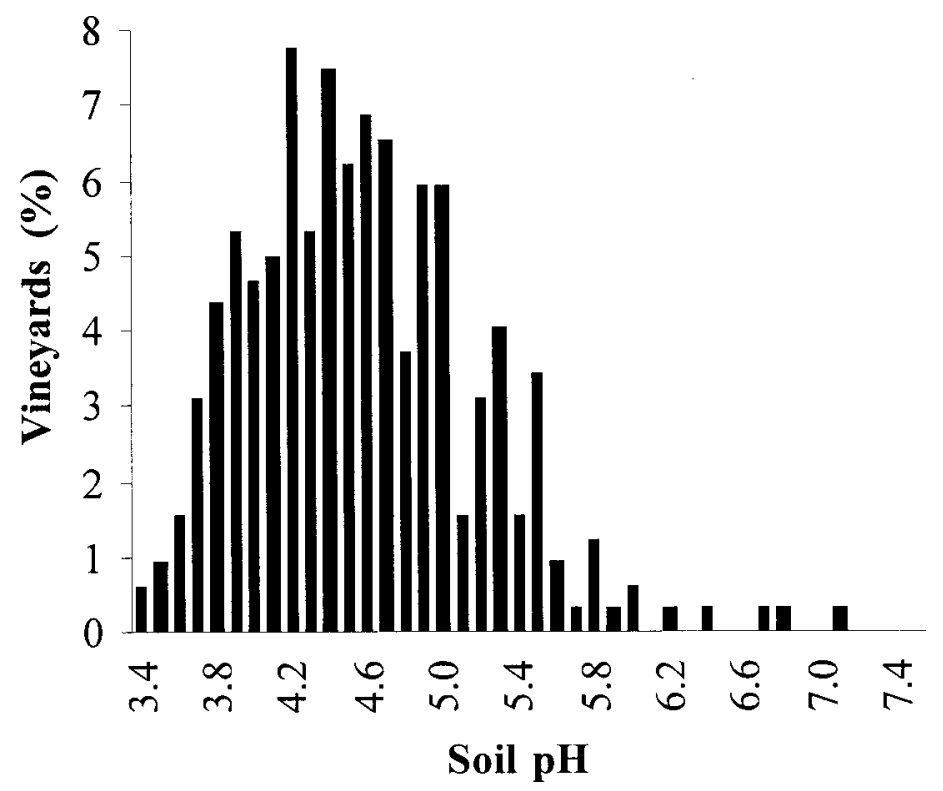

Fig. 1. Soil pH in vineyards in the Lake Erie Regional Grape Belt in 1997 ( $\mathrm{n}=300$ vineyards). 
pound secretion, and beneficial microbial association are all physiological processes roots use to make the rhizosphere a more benign environment for root growth and ion uptake (Marschner, 1986).

Mycorrhizas are the beneficial association between plant roots and mycorrhizal soil fungi (Koide, 1991). Several studies on Vitis vinifera roots document the beneficial association of vesicular-arbuscular mycorrhizae (VAM) in acquiring immobile soil nutrients such as phosphorus (Menge et al., 1983; Possingham and Groot Obbink, 1971; Schubert et al., 1988). VAM infection of or its benefit to 'Concord' roots has not been documented; however, VAM has been shown to play an important role in other acid tolerant species (Sanchez and Salinas, 1981). Phylloxera, a root pest, is common in New York vineyards where it attacks and galls the fine feeder roots of 'Concord' (Stevenson, 1964). Although the galling decreases the fine root surface area of the root system, it is generally accepted that phylloxera is not a major constraint to 'Concord' production (Taschenberg, 1965). However, 'Concord' grafted to 'C3309' phylloxera resistant rootstock has been shown to have greater vine size and yield when compared to own-rooted 'Concord' under identical crop load, canopy, floor, and fertility management (Shaulis and Steel, 1969).

This study investigates the response of newly-planted 'Concord' grapevines to soil $\mathrm{pH}$ and mild nutrient stress. Attention is given to root growth, rhizosphere $\mathrm{pH}$, nutrient absorption, phylloxera nodosities, and mycorrhizae.

\section{Materials and Methods}

Ninety-eight plastic pots with a volume of 94.6 L were filled with vineyard soil and $\mathrm{pH}$ adjusted with dolomitic limestone or ground sulfur. The native vineyard soil was a Chenango gravelly loam with organic matter of $2.5 \%$, CEC of 13.5, and soil $\mathrm{pH}$ of 5.2. Ground sulfur was used to create three soil $\mathrm{pH}$ treatments more acidic than 5.2 and dolomitic limestone was used to create three soil $\mathrm{pH}$ treatments more alkaline than 5.2 (Table 1). The experiment consisted of 7 soil $\mathrm{pH}$ treatments $\times 7$ replicate pots $\times 2$ growing years $=98$ pots. The pots were planted in a row in a completely randomized design.

Soil at the Cornell Vineyard Laboratory in Fredonia, N.Y., was mixed with individual pot soil amendments in a cement mixer. The

Table 1. Target soil $\mathrm{pH}$ values and rates of sulfur ( $80 \%$ effective sulfur) or limestone (85\% effective calcium carbonate) mixed with vineyard soil to achieve those values.

\begin{tabular}{lcr}
\hline $\begin{array}{l}\text { Target } \\
\text { soil pH }\end{array}$ & $\begin{array}{c}\text { Material } \\
\text { used }\end{array}$ & $\begin{array}{r}\text { Rate } \\
\left(\mathrm{t} \cdot \mathrm{ha}^{-1}\right)\end{array}$ \\
\hline $3.5-4.0$ & Ground sulfur & 1.60 \\
$4.0-4.5$ & Ground sulfur & 0.92 \\
$4.5-5.0$ & Ground sulfur & 0.54 \\
5.2 & Check \\
$5.5-6.0$ & Dolomitic limestone & 4.28 \\
$6.0-6.5$ & Dolomitic limestone & 6.75 \\
$6.5-7.5$ & Dolomitic limestone & 10.35 \\
\hline
\end{tabular}

HortScience, Vol. 37(6), OCtober 2002 amended soil was placed into plastic pots (MacKenzie Nursery Supply, Perry, Ohio), which were placed in a 61.0-cm-deep trench. An own-rooted 'Concord' vine (Double A Vineyards, Fredonia, N.Y.) was planted in each pot. The vines were kept well watered for the life of the experiment with drip irrigation.

All vines were pruned back in year one to two shoots after the last threat of spring frost. Soil $\mathrm{pH}$ and leaf area development was monitored during the first growing season. Seven vines from each soil $\mathrm{pH}$ level were randomly selected and destructively harvested on 6 Oct. 1998. Root fresh mass, shoot fresh mass, bulk soil $\mathrm{pH}$, and rhizosphere $\mathrm{pH}$ were measured at harvest. Soil $\mathrm{pH}$ was measured with a $\mathrm{pH}$ meter in a mixture of 50 soil : 50 distilled water (v/v). Bulk soil $\mathrm{pH}$ was determined from soil collected from an area in the pot without grape roots and rhizosphere $\mathrm{pH}$ was determined from soil shaken from the grape roots. After har- vest, vine tissues were dried at $60{ }^{\circ} \mathrm{C}$ for $30 \mathrm{~d}$ and dry mass was measured. Ground leaf and petiole samples were sent to The Pennsylvania State Univ. Agricultural Analytical Services Laboratory (University Park, Pa.) for nutrient analysis. Total nitrogen concentration of each sample was determined by combustion (Campbell, 1991) and other nutrient concentrations were determined through dry ash analysis (Dahlquist and Knoll, 1978).

In year two, the remaining vines were pruned to four shoots after the last threat of spring frost and the vines were defruited $30 \mathrm{~d}$ after bloom. The second-year vines were destructively harvested on 13 Oct. 1999 and measured by the same methods used for yearone vines. Random fresh root sub-samples were collected and phylloxera nodosities were counted on the sub-samples in 1999. The subsamples and main root systems were then dried at $60{ }^{\circ} \mathrm{C}$ for $7 \mathrm{~d}$ and weighed and
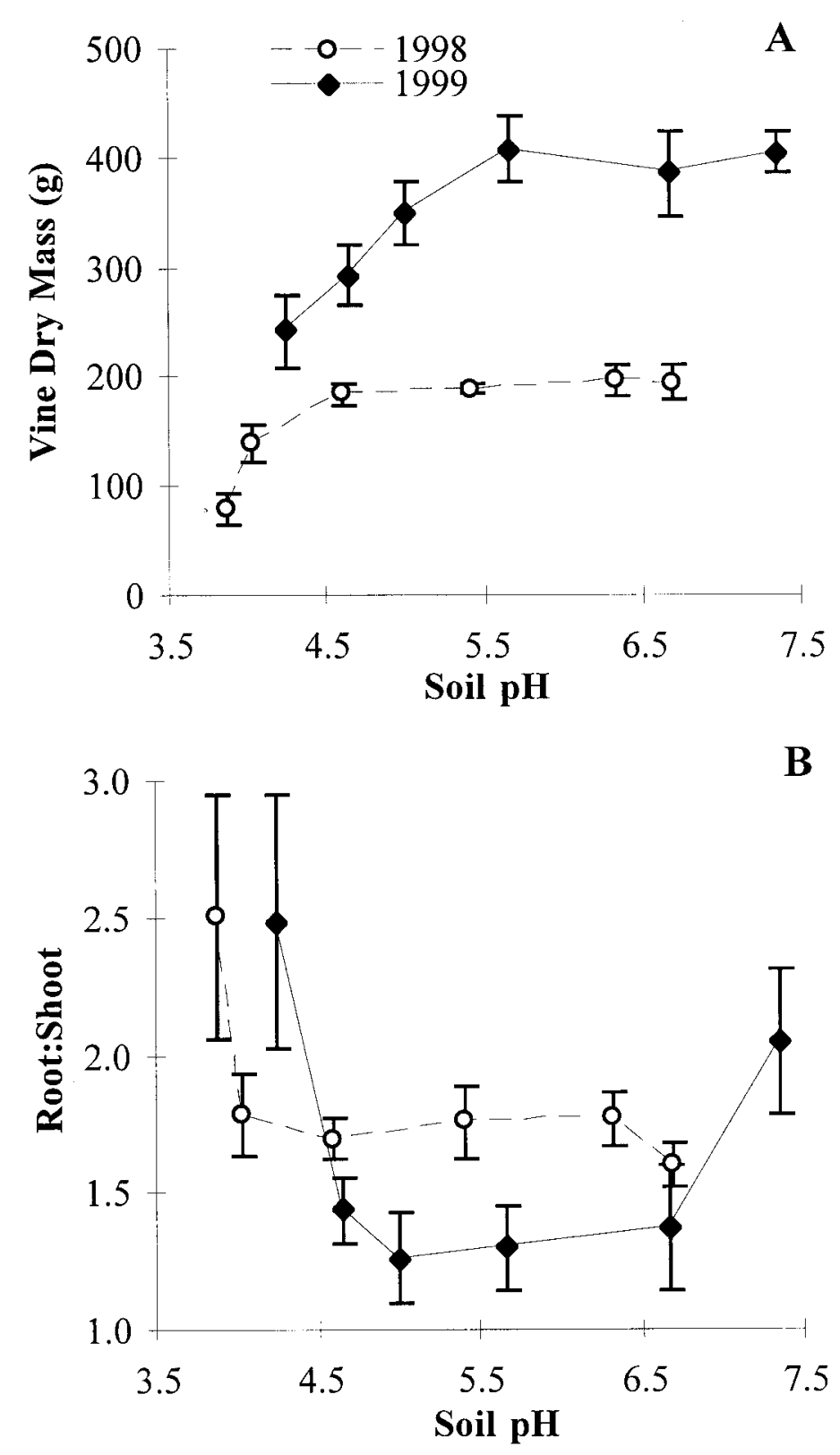

Fig. 2. The effect of soil pH on (A) the vine dry mass and (B) root : shoot ratio of young, pot-grown, 'Concord' grapevines. $(n=6$, bars $= \pm$ SE). 

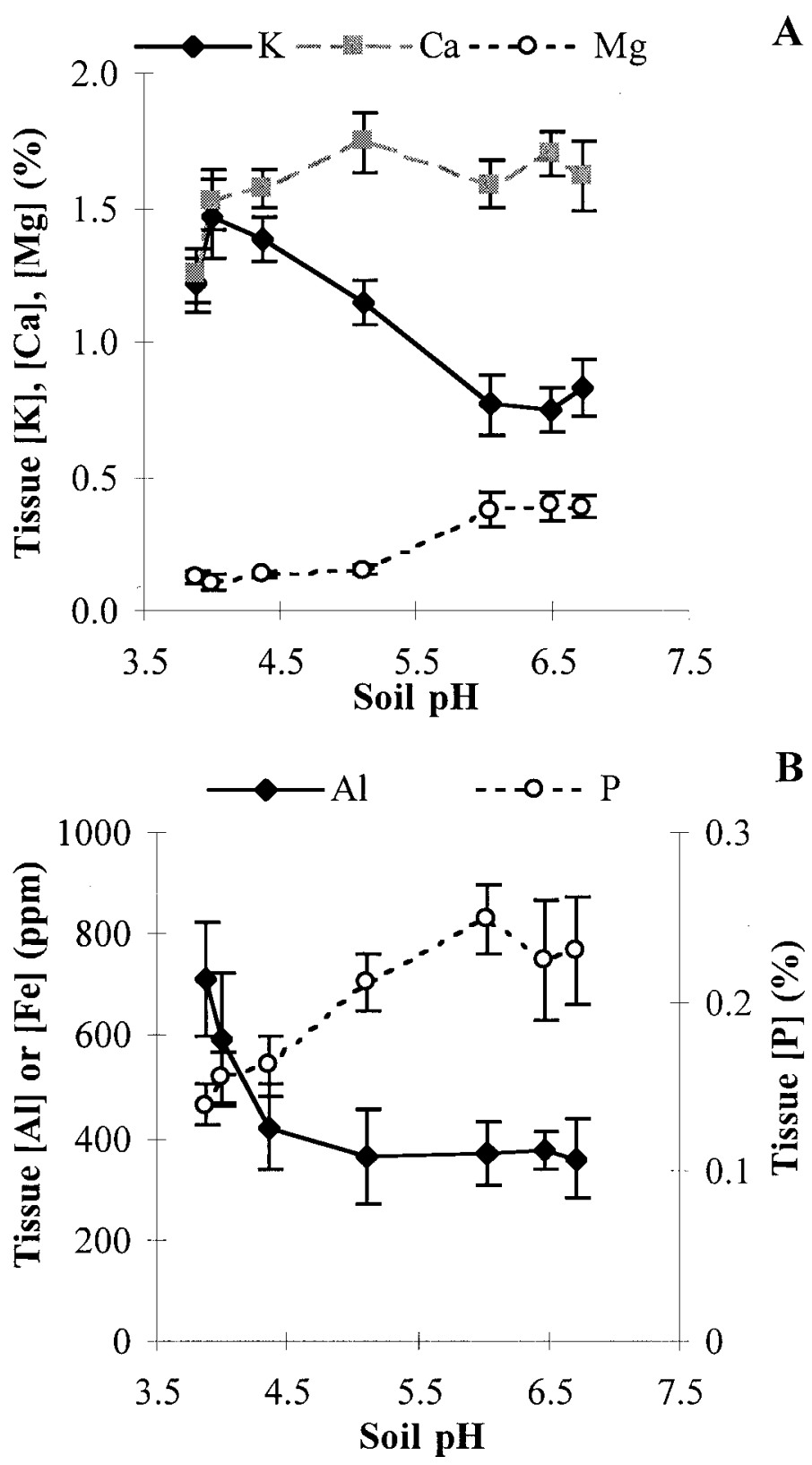

Fig. 3. The effect of soil $\mathrm{pH}$ on fall 'Concord' leaf/petiole tissue concentrations of (A) potassium, calcium, and magnesium or $(\mathbf{B})$ aluminum, iron, and phosphorus. $(n=6$, bars $= \pm S E)$.

phylloxera nodosities per root system were calculated on a dry mass basis. A second fresh root sub-sample was stained for VAM. For VAM staining, fresh roots were cleared for $2 \mathrm{~h}$ in a solution of $5 \%$ potassium hydroxide heated to $80^{\circ} \mathrm{C}$; acidified at room temperature for $12 \mathrm{~h}$ in $1 \%$ hydrochloric acid; stained for $12 \mathrm{~h}$ in a solution of $500 \mathrm{~mL}$ glycerol, 450 $\mathrm{mL}$ water and $50 \mathrm{~mL} 1 \%$ hydrochloric acid and $0.25 \mathrm{~g}$ Typan Blue (Sigma Chemical Co., St. Louis); and destained for $24 \mathrm{~h}$ (destain = staining solution without Typan Blue ). Roots were observed under a dissecting microscope for mycorrhizal infection.

\section{Results and Discussion}

Soil $\mathrm{pH}$ affected total vine biomass and vine root : shoot ratio in both 1998 and 1999 (Fig. $2 \mathrm{~A}$ and B). Results are presented for three ranges of soil $\mathrm{pH}$.
Soil $p H<4.5$. Total vine dry mass decreased and the root : shoot ratio increased below a soil $\mathrm{pH}$ of 4.5 . Low soil $\mathrm{pH}(<4.0)$ decreased potassium and calcium concentrations in 'Concord' grapevine tissue (Fig. 3A). In addition, there was an increase in tissue aluminum and iron below a soil $\mathrm{pH}$ of 4.0 and a decrease in tissue phosphorus below a soil $\mathrm{pH}$ of 4.5 (Fig. 3B). Soil tests indicate that soil aluminum increased from $200 \mathrm{ppm}$ at a soil $\mathrm{pH}$ of 4.5 to $500 \mathrm{ppm}$ at a soil pH of 3.5 (data not shown)

By comparing the bulk soil $\mathrm{pH}$ and the rhizosphere soil $\mathrm{pH}$, vines growing in a bulk soil $\mathrm{pH}$ of 4.0 raised the rhizosphere $\mathrm{pH}$ over $0.4 \mathrm{pH}$ units (Fig. 4). In well-aerated soils, rhizosphere $\mathrm{pH}$ modification is most often attributed to the amount of $\mathrm{H}^{+}$and $\mathrm{HCO}_{3}$ secreted by the roots as a result of differential cation-anion uptake (Marschner, 1986). Acidtolerant species have been shown to increase rhizosphere $\mathrm{pH}$ under acidic and high aluminum soil conditions better than nonacid-tolerant species (Foy, 1992). Minor increases in rhizosphere $\mathrm{pH}$ above 4.0 can greatly reduce the amount and detrimental effects of soluble aluminum (Adams, 1984). However, the importance of rhizosphere $\mathrm{pH}$ in aluminum resistance over other mechanisms, such as organic acid release from the roots, is still in question (Kochian, 1995).

Observations of phylloxera infestation in 1998 prompted the measurement of phylloxera nodosities on excavated roots in 1999. Phylloxera nodosities were present on all roots of the study and there was no effect of soil $\mathrm{pH}$ on the density of phylloxera nodosities (average of 37 nodosities/g root dry mass). However, nodosity counts were also variable (from 3 to 120 nodosities/g root dry mass). Therefore, vines were sorted according to soil $\mathrm{pH}$ and high nodosity density ( $>37$ nodosities/g root dry mass) or low nodosity density $(<37$ nodosities/g root dry mass). There was an interaction of soil $\mathrm{pH}$ and phylloxera infestation on shoot dry mass at the low soil $\mathrm{pH}$ treatments (Fig. 5). Therefore, the combination of low soil $\mathrm{pH}$ and high phylloxera infestation had a greater negative effect on vine growth than did either individual factor.

Soil $\mathrm{pH}$ 5.0-7.0. From a soil $\mathrm{pH}$ of 5.0 to 7.0 , there were no significant differences in vine, shoot, or root biomass. As the soil $\mathrm{pH}$ increased from 5.0 to 6.7 with dolomitic limestone, total tissue cations remained the same; however, there was an increase in tissue magnesium and a decrease in tissue potassium (Fig. 3A). There was also an increase in tissue phosphorus as the soil $\mathrm{pH}$ increased (Fig. 3B).

Although there were no differences in vine size or root : shoot ratio in the 5.0 to 6.7 soil $\mathrm{pH}$ range, there were some differences in rhizosphere $\mathrm{pH}$ (Fig. 4). Vines in a bulk soil $\mathrm{pH}$ of 6.7 decreased the rhizosphere $\mathrm{pH}$ by $0.5 \mathrm{pH}$ units. However, there was little difference between bulk soil $\mathrm{pH}$ and rhizosphere $\mathrm{pH}$ in plants growing in a bulk soil $\mathrm{pH}$ of 5.5 .

Soil $p H>7.0$. There was a trend toward decreased shoot growth (data not shown) with an increased root : shoot ratio above a soil $\mathrm{pH}$ of 7.0 in 1999 (Fig. 2B). Tissue magnesium concentrations were higher and potassium concentrations were lower in the lime treatments (Fig. 3A); however, there were no leaf symptoms of potassium deficiency and plant potassium demand should have been lowered with the crop removal. Similar to the low soil $\mathrm{pH}$ treatment $(<4.5)$, the high $\mathrm{pH}$ treatment $(>7.0)$ had an interaction with phylloxera infestation (Fig. 5). The combination of poor potassium nutrition at high soil $\mathrm{pH}$ and heavy phylloxera infestation may have had a synergistic impact on shoot growth.

VAM were abundant in the subsamples of all the roots and at all soil pH levels. Presumably, all of the vines had mycorrhizae in the nursery and entered the trial with inoculum. Soil pH did not appear to have an effect on infection rate; however, we did not attempt to measure the effect of soil $\mathrm{pH}$ on other aspects of VAM activity such as hyphae growth. 


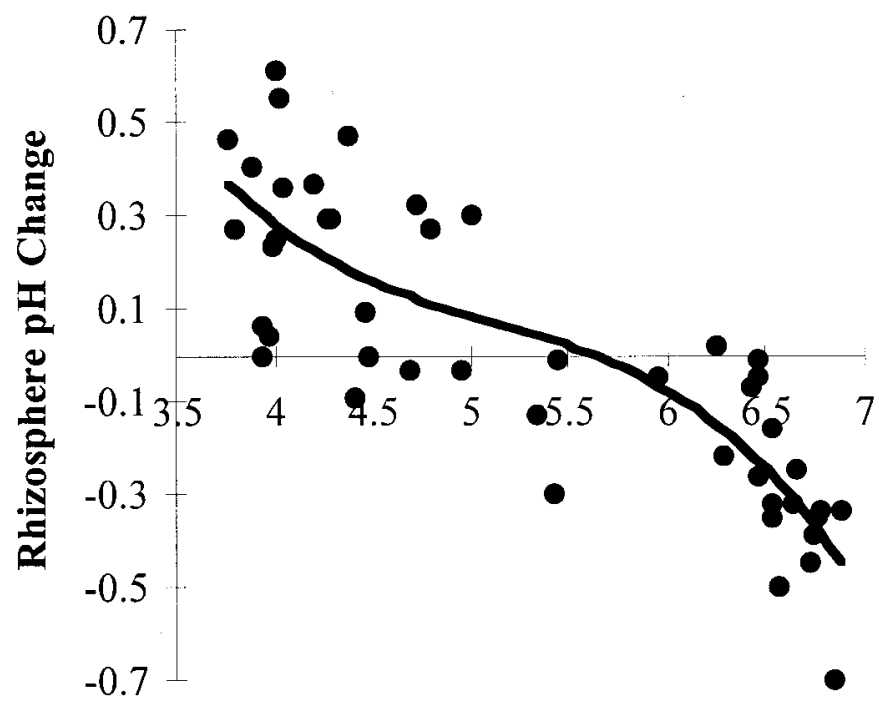

Bulk Soil pH

Fig. 4. The change in rhizosphere $\mathrm{pH}$ around 'Concord' roots from bulk soil $\mathrm{pH}$ over a range of soil $\mathrm{pH}$ levels Positive values represent and increase in rhizosphere $\mathrm{pH}$ and negative values represent a decrease rhizosphere $\mathrm{pH}$ relative to the bulk soil $\mathrm{pH}$.
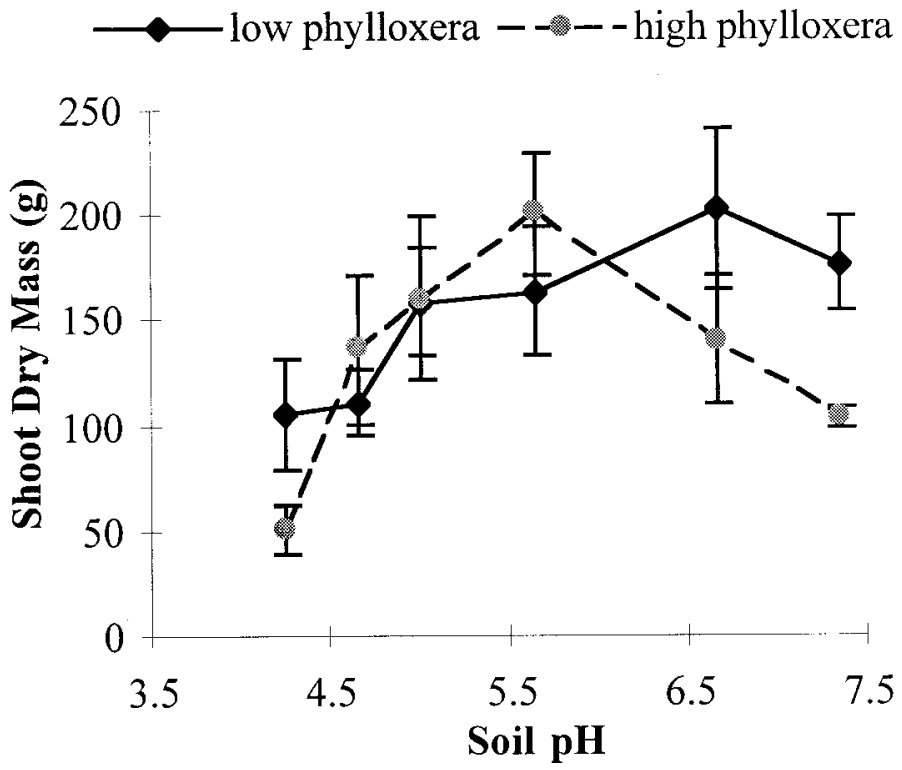

Fig. 5. The interaction of soil $\mathrm{pH}$ and relative phylloxera infestation on 2-year-old 'Concord' shoot dry mass. $(\mathrm{n}=3$, bars $= \pm \mathrm{sE})$.

Combining the measurements of vine biomass, tissue nutrient concentrations, rhizosphere $\mathrm{pH}$, and root health, the optimum soil $\mathrm{pH}$ for young nonbearing 'Concord' vines appears to be between 5.0 and 6.0. In this soil $\mathrm{pH}$ range, the roots are not subject to poor soil chemical conditions such as potentially toxic aluminum levels or phosphorus deficiency. In the acidic soils of the Lake Erie Grape Region, excessive limestone applications to adjust soil $\mathrm{pH}$ to 6.0 or above creates potential problems of calcium, magnesium, and potassium imbalances. 'Concord' grapevine roots show characteristics of acid tolerance through rhizosphere modification and VAM infection. Furthermore, adequate root growth and activity combined with balanced nutrient availability at 5.0-6.0 soil pH allows 'Concord' to overcome the negative effects of high phylloxera infestation.
This study did not investigate the effect of soil $\mathrm{pH}$ and soil $\mathrm{pH}$ adjustment in a mature bearing 'Concord' vineyard. Deep incorporation of soil amendments is difficult in established vineyards, which has complicated the interpretation of similar experiments. Potassium demand in 'Concord' fruit is relatively high and increases with increasing crop level. This may exaggerate magnesium and potassium imbalances in limed 'Concord' vineyards. Soil $\mathrm{pH}$ management in a mature 'Concord' vineyard is under investigation.

\section{Literature Cited}

Adams, F. 1984. Soil acidity and liming. Amer.Soc. Agron., Crop Sci. Soc. of Amer., Soil Sci. Soc. of Amer. Madison, Wis.

Campbell, C.R. 1991. Determination of total nitrogen in plant tissue by combustion. p. 21-23. In:
Plank, C.O. (ed.). Plant analysis reference procedures for the southern region of the United States. Southern Coop. Ser. Bul. 368. Univ. of Georgia, Athens.

Dahlquist, R.L. and J.W. Knoll. 1978. Inductively coupled plasma atomic emission spectrometer: analysis of biological materials and major, trace and ultra-trace elements. Appl. Spectroscopy 32(1): 1-29.

Feuer, R., W.L. Garman and M.G. Cline. 1955. Chautauqua County soils. New York State College of Agr. at Cornell Univ. Soil Assn. leaflet.

Foy, C.D. 1992. Soil chemical factors limiting plant root growth. Adv. in Soil Sci. 19:97-149.

Hanson, E. 1996. Fertilizing fruit crops. Mich. State Univ. Ext. Bul. E-852.

Himelrick, D.G. 1991. Growth and nutritional responses of nine grape cultivars to low soil $\mathrm{pH}$. HortScience 26:269-271.

Kochian, L.V. 1995. Cellular mechanisms of aluminum toxicity and resistance in plants. Annu. Rev. in Plant Physiol. and Plant Mol. Biol. 46:237-260.

Koide, R.T. 1991. Nutrient supply, nutrient demand and plant response to mycorrhizal infection. New Phytologist 117:365-385.

Lathwell, D.J. and W.S. Reid. 1984. Crop response to lime in the Northeastern United States, p. 380. In: F. Adams (ed.). Soil acidity and liming. Amer. Soc. Agron., Crop Sci. Soc. Amer., Soil Sci. Soc. Amer. Madison, Wis.

Marschner, H. 1986. Mineral nutrition of higher plants. Academic, San Diego.

Menge, J.A., D.J. Raski, L.A. Lider, E.L.V.Johnson, N.O. Jones, J.J. Kissler and C.L. Hemstreet. 1983. Interactions between mycorrhizal fungi, soil fumigation, and growth of grapes in California. Amer. J. Enol. Viticult. 34(2):117-121.

Oskamp, J. 1934. Soils in relation to fruit growing in New York. Part V. The vineyard soils of the Westfield Area, Chautauqua County. Cornell Univ. Agr. Expt. Sta. Bul. 609.

Possingham, J.V. and J. Groot Obbink. 1971. Endotrophic mycorrhiza and the nutrition of grape vines. Vitis 10:120-130.

Sanchez, P.A. and G. Salinas. 1981. Low input technology for managing Oxisols and Ultisols in tropical America. Adv. Agron. 34:280-406.

Schubert, A., S. Cammarata, and I. Eynard. 1988. Growth and root colonization of grapevines inoculated with different mycorrhizal endophytes. HortScience 23:302-303.

Shaulis, N. 1961. Associations between symptoms of potassium deficiency, plant analysis, growth, and yield of Concord grapes. Amer. Inst. of Biol. Sci. 8:44-57.

Shaulis, N. and K. Kimball. 1956. The association of nutrient composition of Concord grape petioles with deficiency symptoms, growth, and yield. J. Amer. Soc. Hort. Sci. 68:141-155.

Shaulis, N. and R.D. Steel. 1969. The interaction of resistant rootstock to the nitrogen, weed control, pruning, and thinning on the productivity of Concord grapevines. J. Amer. Soc. Hort. Sci. 91:122-129.

Smith, C.B., H.K. Fleming, L.T. Kardos and C.W. Haeseler. 1972. Responses of Concord grapevines to lime and potassium. Pennsylvania State Univ. College of Agr. Bul. 785:1-36.

Stevenson, A.B. 1964. Seasonal history of rootinfesting Phylloxera vitifoliae (Fitch) (Homoptera: Phylloxeridae) in Ontario. The Canadian Entomol. 96:979-987.

Taschenberg, E.F. 1965. Phylloxera: Does it pose a threat to New York vineyards? New York State Agr. Expt. Sta. Farm Res. 30:2-3.

Waisel, Y., A. Eshel and U. Kafkafi. 1996. Plant roots-The hidden half. Marcel Dekker, New York. 